nervous system, and investigations of the physiological effects of strychnine have shown that it lowers synaptic thresholds at low concentrations while increasing them at high concentrations. It has also been suggested that strychnine has facilitative effects on performance, since it increases visual acuity.

The work recorded here was undertaken to provide a test of the hypothesis that injecting rats with strychnine after each trial will facilitate maze learning. Evidence of retroactive facilitating effects would strengthen the hypothesis that strychnine facilitates learning rather than performance and further support the perseveration hypothesis of learning.

At the time of this report, 40 animals have completed the testing procedure. Twenty were from the $S 1$ strain and twenty were from the $S 3$ strain. Both these strains are descendants of the Tryon maze-bright (S1) and maze-dull $(S 3)$ strains. All animals were 70-82 days old at the beginning of the experiment. The animals were first pretrained for 9 days, and were put on a food-deprivation schedule so as to reduce their body-weights 15 per cent below normal. On the ninth day of pretraining the animals were assigned to four groups which were matched on the basis of pretraining running times and body-weights. They were then run 1 trial a day on a 14-unit automatically recording alley maze, and injected interperitoneally $1 \mathrm{~min}$ or $1 \mathrm{~h}$ after each daily trial with either a strychnine sulphate or a normal saline solution.

The results of the examination support the original hypothesis that injections of strychnine administered after each daily trial did facilitate the rate at which rats learn a 14-unit maze. However, a more detailed analysis of the data revealed a strain difference. The maze-dulls when injected with strychnine I min after trial made significantly fewer errors than did the maze-brights receiving strychnine 1 min after trial. Furthermore, a strain difference was also observable at the 1 -h interval; whereas the mazebrights were facilitated when injected with strychnine at both the 1-min and $1-h$ intervals, the dulls were facilitated only at the 1-min interval. No facilitative effects of strychnine were found with the dulls at the l-h interval.

A. possible interpretation of these findings is provided by the hypothesis that learning efficiency depends on the ratio of acetylcholine (A.Ch) to cholinesterase (ChE) in the central nervous system. Neural transmission involves the release of ACh by presynaptic nerve endings. ACh is a neural stimulant when it is present in small amounts, but paralyses transmission when it accumulates beyond a critical level. Consequently, ACh must be inactivated rapidly after it is released. The enzyme ChE has been shown to perform this important function by hydrolysing the ACh almost instantaneously. The injections of strychnine, which is an anti-cholinergic drug, should allow a functionally greater amount of ACh to be present in the central nervous system.

Thus it is hypothesized that efficient learning is produced by a ratio of $\mathrm{ACh}-\mathrm{ChE}$ which is optimal for efficient neural reverberation. If the amount of reverberatory neural activity depends on the ratio of $\mathrm{ACh}-\mathrm{ChE}$, then, within limits, the higher the ratio the more reverberatory activity and the longer the perseveration period.

The results also suggest that the maze-dulls have a ratio of $\mathrm{ACh}-\mathrm{ChE}$ which is less than optimal for neural reverberation, since injections of strychnine at the 1 min interval produced significant facilitation while no facilitating effects were found at the $1-h$ interval. Presumably this is because the reverberatory neural activity underlying perseveration is rapidly dissipated due to a low ratio of A.Ch-ChE. In other words, the ChE hydrolysed the A.Ch too quickly, thereby shortening the perseveration period. This hypothesis also suggests that differences in perseveration time found by other investigators might be due to strain or species differences in A.Ch-ChE ratios.

Finally, it should be pointed out that these are preliminary results and that a more detailed analysis of the data when all the animals have been run may shed more light on the strain difference already noted.
Department of Psychology,
Richard B. Ross

University College, London.

${ }^{1}$ Hebb, D. O., The Organization of Behavior (Wiley, New York, ]449). 'Muller, G. E., and Pilzecker, A., Z. Psychol., 1 (1900).

3 Duncan, C. P., J. Comp. and Physiol. Psychol., 42, 32 (1949).

4 Gerrard, R. W., Science, 122, 225 (1955).

${ }^{5}$ Leukel, F., J. Comp. and Physiol. Psychol, 50, 300 (1957).

'Thompson, R., J. Comp. and Physiol. Psychol., 50, 397 (1957).

\section{HISTORY OF SCIENCE}

\section{An Observation of the Interference of Light of Higher Orders in 1646 and its Response}

During 1599-1660 there lived, in Bohemia, Balthasar Conrad, a professor in the Universities of Prague and Olomouc. Under his leadership several candidates defended their theses on diverse physical subjects.

In 1646 such a thesis entitled 'De natura iridis' was defended by Balthasar Melchior Hanél (1627-89). This dissertation is interesting in that it describes an observation of the interference of light of higher orders.

At that time astronomers used a camera obscura for measurement of the fictitious diameter of the Sun. These measurements were intensively carried out by Christofor Scheiner (1575-1650), who also made his observations in Prague.

Scheiner's experiments with a more suitable camera obscura were repeated by Conrad and Haněl. While Scheiner made his observations with an open camera obscura in a more or less obscured room (Rosa Ursina, Braccianum 1626-30, Figs. on pp. 150, 353), Conrad constructed a special long hollow prism. Through a small aperture in its front side he mapped the Sun on a sheet of paper or observed it with his head inside the prism. Making these observations, he noticed multiple 'rainbows' around the Sun as described in the dissertation: "Itaque observaturus diametrum Solis praecipue, feceram mihi parallelepipedum cavum, facile 10 pedum. Idque undique bene communiveram contra lucem incidentem, summas enim tenebras volebam intus habere. Tamen versus Solem modicissimo foramine aperui et sic coepi, immerso etiam capite in illud cavum, observare diametrum Solis. ... Cum ergo transpiciendo per tale foramen appareant Irides circa Solem ...."

But Conrad observed this phenomenon also without its long prism: "Accipio orichalceam laminam, eamque in foramen rotundum, minimum, alicubi pertundo ... tum per id foramen adspicio Solem. Et ecce Solem circumdatum Iride primaria conspicor. Imo aliquando plures quam unam circa Solem Iridem deprehendi."

The phenomenon was also shown to Scheiner, who, as the authors of the dissertation mention, was surprised at it.

The authors explain this phenomenon by the refraction of sunbeams in drops of water present in the air: "... non videtur posse esse haec emphasis reflexio a crasso foraminis, sed debet esse refractio Solis per guttas vapidas aëri innatantes."

Ioannes Marcus Marci de Cronland (1595-1667), professor in the University of Prague, responded to Hanèl's dissertation by a disputation of the same title 'De natura iridis' in 1650. Earlier Marci published a book entitled Thaumantias... (Prague 1648), which dealt with the rainbow and colours in which he described observations of the diffraction of light on a wire, edge, aperture and through a lattice ${ }^{1}$. In the disputation Marci accepts without comments the existence of the described phenomenon, but he disagrees with the authors concerning its explanation. According to Marci the phenomenon has its origin in the refraction of sunbeams in the eye liquors of the observer and not in drops of water in the air.

J. Marek

Institute of Metallurgy, Prague.

${ }^{1}$ Marek, J., Nature, 190, 1092 (1961). 